\title{
ONCOLOGIC PAIN RELIEF: STRATEGIES TOLD BY ADOLESCENTS WITH CANCER
}

\author{
Amanda de Fatima Portugal Rocha ${ }^{1}$, Amanda Mota Pacciulio Sposito ${ }^{2}$, Paula Saud de Bortoli, Fernanda \\ Machado Silva-Rodrigues ${ }^{4}$, Regina Aparecida Garcia de Lima ${ }^{5}$, Lucila Castanheira Nascimento ${ }^{6}$
}

${ }^{1}$ RN. Escola de Enfermagem de Ribeirão Preto (EERP) da Universidade de São Paulo (USP). Ribeirão Preto, São Paulo, Brazil. E-mail: amandafatima28@hotmail.com

${ }^{2}$ M.Sc. in Sciences. Occupational Therapist, University of São Paulo at Ribeirão Preto Medical School Hospital das Clínicas (HCFMRP-USP). Ribeirão Preto, São Paulo, Brazil. E-mail: amandamps.to@gmail.com

${ }^{3}$ M.Sc. in Sciences. Pediatric nurse at HCFMRP-USP. Ribeirão Preto, São Paulo, Brazil. E-mail: pauladebortoli@eerp.usp.br

${ }^{4}$ M.Sc. in Sciences. Pediatric nurse at Hospital Infantil Darcy Vargas. São Paulo, São Paulo, Brazil. E-mail: fmachadosilv@gmail. com

${ }^{5}$ Ph.D. in Nursing. Full Professor at Maternal-Infant and Public Health Nursing Department of EERP-USP. CNPq researcher. Ribeirão Preto, São Paulo, Brazil. E-mail: limare@eerp.usp.br

${ }^{6}$ Ph.D. in Nursing. Associate Professor at Maternal-Infant and Public Health Nursing Department of EERP/USP. CNPq researcher. Ribeirão Preto, São Paulo, Brazil. E-mail: lucila@eerp.usp.br

\begin{abstract}
In view of the negative impact of pain on the quality of life of cancer patients, identifying and stimulating the use of effective strategies to minimize these painful feelings is highly relevant for care. The aim of this study was to identify painful experiences of adolescents with cancer and to get to know their strategies for pain relief. This is an exploratory research, using qualitative data analysis. Semistructured interviews were held with nine adolescents with cancer, who reported on acute, recurring and chronic, physical and emotional painful experiences. To relieve these pains, they described pharmacological and non-pharmacological strategies, including: distraction, presence of relatives, bed positioning, cooperation to accomplish procedures and keeping up positive thinking. Therefore, it is essential for health professionals to know available evidence for pain relief and to develop skills to articulate this knowledge with their professional experience and with the patients' own strategies.
\end{abstract}

DESCRIPTORS: Adolescent. Neoplasms. Pain. Pediatric nursing.

\section{O ALÍVIO DA DOR ONCOLÓGICA: ESTRATÉGIAS CONTADAS POR ADOLESCENTES COM CÂNCER}

RESUMO: Tendo em vista o impacto negativo da dor na qualidade de vida do paciente oncológico, identificar e estimular o uso de estratégias eficazes para minimizar essas sensações dolorosas é de grande relevância para o cuidado. Este estudo objetivou identificar experiências dolorosas de adolescentes com câncer e conhecer suas estratégias para o alívio da dor. Trata-se de um estudo exploratório, com análise qualitativa dos dados. Foram realizadas entrevistas semiestruturadas com nove adolescentes com câncer, os quais relataram experiências dolorosas agudas, recorrentes e crônicas, tanto físicas quanto emocionais. Para o alívio dessas dores, descreveram estratégias farmacológicas e não farmacológicas, tais como: distração, presença de familiares, posicionamento no leito, colaboração para realizar procedimentos e manutenção de pensamento positivo. Assim, é essencial que os profissionais de saúde conheçam as evidências disponíveis para o alívio da dor e desenvolvam habilidades para articular esse conhecimento à sua experiência profissional e às estratégias dos próprios pacientes.

DESCRITORES: Adolescente. Neoplasias. Dor. Enfermagem pediátrica.

\section{EL ALIVIO DEL DOLOR ONCOLÓGICO: ESTRATEGIAS CONTADAS POR ADOLESCENTES CON CÁNCER}

RESUMEN: Ante el impacto negativo del dolor en la calidad de vida del paciente oncológico, identificar y estimular el uso de estrategias eficaces para minimizar esas sensaciones dolorosas es muy relevante para el cuidado. El objetivo de este estudio fue identificar experiencias dolorosas de adolescentes con cáncer y conocer sus estrategias para aliviar el dolor. Estudio exploratorio con análisis cualitativo de los datos. Fueron realizadas entrevistas semiestructuradas con nueve adolescentes con cáncer, que relataron experiencias dolorosas agudas, recurrentes y crónicas, físicas y emocionales. Para aliviar esos dolores, describieron estrategias farmacológicas y no farmacológicas, tales como: distracción; presencia de familiares, posicionamiento en el lecho, colaboración para efectuar procedimientos y mantenimiento de pensamiento positivo. Así, es fundamental que los profesionales de salud conozcan las evidencias disponibles para el alivio del dolor y desarrollen habilidades para articular ese conocimiento a su experiencia profesional, así como estrategias de los propios pacientes DESCRIPTORES: Adolescente. Neoplasias. Dolor. Enfermería pediátrica. 


\section{INTRODUCTION}

Pain is a symptom that is frequently associated with cancer. According to the International Association for the Study of Pain, pain is an unpleasant sensory and emotional experience associated or related with actual or potential tissue damage. In addition, it is considered that each individual uses the term pain and classifies its intensity based on his/her personal experiences. ${ }^{1}$

After analyzing the literature in the area, authors $^{2}$ estimated that the prevalence of pain ranges between $9 \%$ and $26 \%$ for pediatric outpatient cancer patients and between $39 \%$ and $54 \%$ for children and adolescents hospitalized for treatment. Another study ${ }^{3}$ reviewed the literature on the most common symptoms in adolescents with cancer and identified that the causes of pain in that population vary over time. In the diagnosis, pain is mainly related with the cancer itself but, in the course of the treatment, it turns into a consequence of the treatment itself and procedures. The painful sites the adolescents most mentioned were: head, back, limbs, mouth and abdomen. ${ }^{3}$

In the pediatric cancer population, historically, pain has been ignored or precariously treated. Since the previous decade, however, the attitudes that promoted its insufficient treatment and clinical practice standards have changed, ${ }^{4}$ indicating the importance of assessment for the early identification and measuring of pain, as well as for effective treatment in each case. The fact that the pain is not correctly measured or undertreated can cause physiological alterations, limitations in the patients' accomplishment of their daily activities, restrictions in the interaction with other people, losses of sleep quality and in the learning process. ${ }^{5}$

In view of the negative impact of pain in the quality of life of cancer patients, identifying and stimulating the use of effective strategies to minimize these painful feelings is very relevant in the care context ${ }^{6}$ and, whenever possible, it should be treated preventively, thus avoiding all of the suffering associated with this condition. ${ }^{4}$

An analysis of the Brazilian scientific production about pediatric cancer, published between 2000 and 2009, indicated the need for further research on the experience of adolescents with cancer, ${ }^{7}$ which is significantly permeated by painful experiences. ${ }^{8}$ Adolescence is a period of intense physical, psychological and social development, during which the adolescents gain further responsibility and autonomy, becoming increasingly dependent on the caregivers. ${ }^{9}$ It is considered that, due to this greater independence, the adolescents themselves are the best source of information about their painful experience related to the cancer and its treatment, as well as effective strategies to relieve their pain, contributing to the excellence of cancer pain management.

Thus, the objective in this study is to identify the painful experiences of adolescents undergoing cancer treatment and to get to know the strategies these clients use for pain relief.

\section{METHOD}

Exploratory study with qualitative analysis of the data. The study was undertaken at a tertiary university hospital located in an interior city in the State of São Paulo. It was submitted to the Ethics Committee of the research institution, in compliance with CNS Resolution CNS 196/96, ${ }^{10}$ in force at that time, and received approval (Protocol $n$. 1204/2010).

As part of the documentation established in this law, the Free and Informed Consent Form was elaborated, in clear and accessible language, to inform the research subjects about the objectives; the data collection procedures; possible constraints or benefits; guarantees of secrecy and respective for the desire to participate in the research or not. This document was read and discussed with each of the study participants, together with their mothers, before the start of the data collection. All mothers were asked to sign the Form, authorizing their children's participation in the research, as well as the recording of the interview. Besides the mothers' consent, all participating adolescents gave their assent.

Adolescents between 12 and 18 years of age were selected, diagnosed with any kind of malign tumor and who were under treatment at the institution selected to develop the research for at least six months or due to a relapse of the disease.

As a data collection technique, semistructured interviews were used to identify the patients' painful experiences and get to know the strategies adopted to relieve their pain during the cancer treatment, from their own experience. 
The interviews were held between August 2010 and March 2011, at the hospitalization ward (in the participants' rooms) and in the waiting room of the onco-hematology outpatient service of the research institution. To explore the research problem, only one meeting was needed with each adolescent. The adolescents could choose whether to have the interview in their mothers' presence, who accompanied them at the service, which some participants accepted.

For the purpose of initial contact and avoiding to directly discuss the pain, which could make the participants feel uncomfortable, the following guiding question was elaborated: tell me what your daily life has been like since you have started treatment. Based on that interaction, the interviewer used the opportunity to explore the moments of satisfaction and dissatisfaction that permeated the treatment, including the painful experiences. Next, the pain and relief strategies were explored in depth.

To complement the data collection, the adolescents' clinical histories were analyzed to obtain detailed information on the diagnosis, therapeutic experiences and time since the start of the treatment until the moment of the data collection.

The interviews were fully transcribed to preserve the participants' statements and submitted to content analysis. ${ }^{11}$ Thus, first, the empirical material was read exhaustively, identifying words, phrases and concepts. Next, the data were categorized, an essential phase in this phrase, when the information was organized in the framework of the research objectives and results. Finally, the categories were integrated in broader themes in order to represent the adolescents' painful experiences and the strategies they chose for pain relief. In the presentation of the selected statements to illustrate these themes, the letter $\mathrm{P}$ was used to represent the research participants.

\section{RESULTS}

Nine adolescents participated in the research, between 12 and 17 years of age, totaling nine participants. Six of them were female and three male.

As regards the adolescents' diagnosis, the following were found: central nervous system tumor (three), bone tumors (three), soft part sarcoma (one), lymphoma (one) and leukemia (one). The length of treatment ranged between six and 17 months. Concerning the treatment type, seven participants had already been submitted to surgery, eight received chemotherapy and three radiotherapy.

The qualitative analysis process permitted the identification of two themes, organized and presented as follows: pain and painful experience reports of adolescents undergoing cancer treatment, and cancer pain relief.

\section{Pain and painful experience reports of adolescents undergoing cancer treatment}

In the testimonies, all participants mentioned painful procedure-related situations and unanimously attributed pain related to venipuncture for medication and chemotherapeutic administration and test collection. Others also referred to the postoperative pain and pain provoked by biopsies, which can be characterized as acute pain: the part of keeping on pricking [causes pain]. Ah, to take the medicine they always prick [the vein] and they always have to take blood. Ouch, it's a prick each day [...]. The worst pain I feel is to do the Zoladex ${ }^{\circledR}$ [medication], which is in the belly [...]. But the worst, worst, worst was the biopsy I did! The biopsies are very... [does not find words to express her pain] (P1, female, 17 years); ah, the worst was when I amputated my leg. Ah, when I was operated on it hurt a lot! Even if it rained it hurt [...]. Uh! The pricks, oh dear! The pricks hurt! (P3, male, 16 years).

The increased anxiety, fear and concern related to frequent invasive procedures make them even more painful, as illustrated in the following discourse: the pain is not always very strong, not always, but the psychological effect of knowing that it is going to hurt, then it ends up hurting more! [...]. That's how we are afraid in advance! (P1, female, 17 years); ah, I feel pain like, sometimes it hurts a little, sometimes it hurts a lot. Then I get concerned whether it's going to hurt a lot or a little [...]. Sometimes, after the prick, sometimes the vein bursts, then I get scared that that might happen (P5, female, 12 years).

Another painful experience the participants mentioned was related to the chemotherapy treatment and its side effects, including those associated to the frequent episodes of vomiting and stomach ache, which were the most reminded and expressive events, characterizing recurring 
and chronic pain: ah, since I've been doing the treatment I've got pain in my stomach (P4, male, 12 years); ah, yes, I do feel a bit of pain [referring to the side effects of the chemotherapy] in the entire esophageal canal, in the digestive part as a whole (P9, male, 16 years).

Cancer pain reports directly linked to the tumor were observed in some participants' descriptions, especially when talking about the pains preceding the diagnosis and the start of the treatment: because I didn't know I had a tumor. Then I had a lot of headache, my head hurt a lot and I was feeling sick ( $\mathrm{P} 4$, male, 12 years).

Some adolescents referred to even more subjective pain experiences, which they characterized as "emotional pain" or "grief", triggered by the cancer diagnosis and treatment: that is worse [than the physical pain]. Like the hair, because we know that one moment the [physical] pain is going to pass, perhaps in one hour, two hours. Just that, when you shave your hair, it starts to fall out, you know, it won't grow immediately. So [interrupts her statement]. It's very sad, you feel embarrassed, really downhearted, you feel ashamed that other people might laugh at you (P1, female, 17 years); the pain I feel most is grief, because I did not want to be in this situation, like, the way it happened (P7, female, 13 years); ah, the restrictions the treatment ends up causing [characterize subjective pain experience]. For example, between us, a 16-year-old adolescent needs social contact [...] needs, not a girlfriend, but a flirt, something like that, and treatment does not allow that. It's not easy, not easy, let's say, you change from a completely free world to world closed inside a plastic ball (P9, male, 16 years).

\section{The relief of cancer pain}

The adolescents described different strategies they adopt to relieve the pain deriving from cancer and its treatment, which can be presented in two main groups: non-pharmacological strategies and pharmacological strategies.

\section{Non-pharmacological strategies}

Among the non-pharmacological strategies, distraction was the one the participants mentioned most, who indicated the benefits of talks and playful activities, such as: listening to music, watching television, reading, playing videogame, driving the bicycle, walking and using the computer: $a h$, music improves [the pain] a bit! (P3, male, 16 years) [...] like, you're a bit entertained, then you are no longer thinking of the pain, then it seems like it disappears like magic. Then I'm always listening to music, before I sleep I read a book, watch a lot of television, DVD, so that helps a lot (P6, female, 12 years); well, I watch TV, call someone, I sleep, try to talk to someone. I even read a book some time ago that said that, that distraction is the best thing to forget and even to control pain. (P9, male, 16 years).

Distraction is not only defined as an intrinsic characteristic of play, but can also be an important auxiliary tool to cope with acute painful situations, such as venipuncture, as illustrated in the following excerpts: ah, sometimes I put Luizinho [cuddle lion] on my face like this, sometime I look at my mom, squeeze her and bite Luizinho (P5, female, 12 years).

The participants unanimously considered the family's presence and the affection of all loved ones as important and fundamental to mitigate the physical or emotional pain and overcome these painful moments. Some indicated the need for the mother's presence only, while others cited the importance of the entire core family, friends and loved ones' support and affection: three people [are fundamental to minimize the pain]: my mother, my grandmother and my cousin [...]. I think, like, all mothers have a gift that ends up comforting the child simply by looking (P9, male, 16 years); there was one thing that used to help me a lot: my mom. Because, whenever I need her, she's there with me, she has never left me, and without a person who helps, it's more difficult (P7, female, 13 years); let's say [...] with other emotional pain, when I was still dating, I looked for attention, kindness, [...] sometimes a hug, you know, caressing? Ask for caressing until you fall asleep, [...] a bit of pampering ( $\mathrm{P} 9$, male, 16 years).

Other relief strategies the adolescents in this study adopted were: cooperating with the procedures, taking on appropriate positions during the procedures and staying positive: ah, generally I close y hand, put my arm correctly and turn over, I don't watch so as not to feel even more stressed, because I know that, if I move my arm, refuse to take this prick, it will be much more difficult and hurt more (P4, male, 12 years); then I'd soften my arm and did not look and tried to think of other things (P8, female, 12 years).

A 12-year-old adolescent (P2) added that, to mitigate the pain during that procedure, she remained positive: ah, I used to think that everything would work out! 
The adolescents also indicated the search for comfort measures to mitigate the pain, like taking a shower and lying down for example, or keeping silent, searching a calm environment: I used to take a shower and lie down, and tried to watch television (P7, female, 13 years); ah, since I've been doing the treatment I've got stomachache, but it goes by quickly. Then I stay still, like, calm, then it passes [...]. I sit down in a corner, stay still and quiet, wait for it to pass (P4, male, 12 years); for headache I lie down, try to sleep a little [...] (P6, female, 12 years).

Finally, another non-pharmacological measure the participants mentioned as a pain relief strategy was praying. A 12-year-old adolescent (P4) mentioned asking Jesus for relief when in pain and considered that this helps him for the painful feeling to pass faster. The interviewer's dialogue with a 12-year-old adolescent (P6) also illustrates the role of prayer in pain relief:

Participant: you always have to pray either an Our Father or a Hail Mary.

Interviewer: so you pray and think that helps you to reduce the pain?

\section{Participant: it helps a lot!}

\section{Pharmacological srategies}

Besides the non-pharmacological interventions, for the sake of an effective therapy, they often had to be associated with pharmacological interventions. Thus, some of the interviewees mentioned asking for medication when the pain is very strong. Nevertheless, they considered that the medication alone did not always relieve their pain: no, I don't like it, I only ask for it [the medication] when I feel very bad. (P8, female, 12 years); generally, for stronger pain, when it's very intense, I try to take the medication and distract myself because, if I don't, I keep on thinking: the medicine has not worked yet. Then it seems that the pain gets stronger (P9, male, 16 years); then I was concerned with feeling more pain and, sometimes, I kept on asking for some medication to see if the pain would pass. Just that, sometimes, it was no use. Then they had to use some stronger medicines (P6, female, 12 years).

In his testimony, a 16-year-old adolescent (P3) revealed that he didn't find means to relieve his pain: only when it passed really. He added that he took medication but that, nevertheless, he did not feel the relief for his pain: yes, I used to take medication!

\section{DISCUSSION}

Each individual uses the term pain according to his/her traumatic experiences, sociocultural context, personality type and life history. Therefore, it is known that the perceived pain and pain response are not only neurophysiological phenomena, exclusively based on the transmission of painful stimuli, but are also influenced by one's thoughts, emotions and memories. ${ }^{12} \mathrm{~A}$ literature review ${ }^{13}$ indicated that children and adolescents who are submitted to frequent invasive procedures, without concerns with minimizing the pain these interventions provoke, can develop: anticipatory anxiety; greater sensitivity to pain, due to the changes in the way the central nervous system processes the painful stimuli, leading to the reduced efficacy of analgesics; fear and difficulty to accept further procedures.

Among the invasive procedures, pediatric cancer patients frequently mention venipuncture as a cause of pain, anxiety and tension, converging with other study results, ${ }^{3,5,14}$ which mention venipuncture, besides lumbar puncture and bone marrow test collection, ${ }^{3,5}$ as the main causes of pain in the pediatric population undergoing cancer treatment.

The intravenous route is constantly used for medication administration and diagnostic and auxiliary tests in pediatric oncology ${ }^{15}$ but the frequent use of the venous network compromises its integrity. In addition, many chemotherapeutic drugs have vesicant and irritating effects, making the veins even more fragile and worn. ${ }^{16}$ Hence, the use of the peripheral route for repeated punctures generally provokes intense pain in these patients, justifying the placement of central venous catheters, which contribute to minimize the painful feelings and reduce the patients, family members and nursing team's stress. ${ }^{15}$

As regards the side effects of chemotherapy, vomiting and stomach ache were the most mentioned in the adolescents' discourse, as well as in two other studies. ${ }^{14,17}$ In that sense, it is important to highlight that, for the research participants, vomiting was associated with stomachache, differently from nausea, which is also a symptom and which was related to the negative hospitalization experiences, but which the adolescents did not characterize as pain. In general, the interviewees referred to stomachache as being chronic. 
This relation between episodes of vomiting and pain in the gastrointestinal tract is in line with literature data that relate these symptoms with therapy using antineoplastic drugs (chemotherapy-induced nausea and vomiting) in the adolescent population. ${ }^{3}$ As they extend throughout the treatment, vomiting and stomachache interfere negatively in the diet and can make the patients refuse to eat. Including the adolescents' preferred foods into the diet can minimize this, in line with the medical recommendations. ${ }^{17}$

Pain, whether chronic or acute, is characterized as a multidimensional phenomenon, and the adolescents' reports related to the total pain concept, which refers not only to the nociception of pain (physical element), but also to the suffering the individual's psychic, social and spiritual dimensions cause. ${ }^{18}$ Pain assessment is not an easy task, due to its subjectivity and multiple dimensions, which makes this even harder in care for the pediatric population. Nevertheless, the assessment is fundamental for the quality of care, as pain that is not identified and described is not treated. ${ }^{19}$ Therefore, the activities of professionals who are skilled to articulate and share their knowledge with other people is fundamental and, mainly, who are sensitive to listen to patients in this age range, in the attempt to apprehend, based on their different forms of expression, how they experience the painful feelings in their physical, mental and social dimensions, and what relief strategies will be more effective in each case.

To achieve the best result in pain relief, strategies need to be combined. As observed, the study participants used pharmacological measures when the pain was more intense. The literature suggests that adolescents can reduce the dose and frequency of medication for pain relief on their own account, or tolerate moderate and continuing pain without the parents and professionals knowing as, for them, the pain can be related to feelings of weakness, dependence and constraint in view of their peers. ${ }^{5}$

The combination between non-pharmacological and pharmacological methods the participants mentioned indicates the different actions of each modality. While the analgesic medication administration interferes in the sensory pain dimensions, the non-pharmacological measures act on other components, such as the mood, behavior and emotional response to the painful situation. ${ }^{20}$
Among the non-pharmacological strategies, the interviewees cited and used distraction most frequently, perhaps due to the range of possibilities or the easy access to the resources needed. Distraction refers to focusing one's attention on another stimulus than the pain, and one of its main goals is to help and manage the anxiety before potentially painful procedures..$^{21}$ It is recommended when there is insufficient time to prepare the children and adolescents for the procedures and involves a large range of techniques, from the simplest, like counting (numbers), singing, to the most elaborate ones, like watching a video or using play and games. ${ }^{21}$

As a result of the hospitalization needs of children and adolescents with cancer, often, the affective bonds between parents and children are tightened and strengthened and, frequently, the sick child turns into the focus of attention, due to the weakness the disease causes. Over time, the family stops being a spectator at the hospital and becomes a participatory agent in the treatment, besides serving as a protective elements of the children and adolescents' emotional, cognitive and social aspects, entailing a new form of care, the so-called family-centered care. ${ }^{22}$ Therefore, in their practice, it is fundamental for nurses to reflect on how they share the care for adolescents in pain with the parents, attempting to active and effectively engage them in pain management. Thus, they will certainly contribute to the construction of positive and more comforting experiences in the course of the hospitalization, for the patients as well as the families. ${ }^{23}$

Promoting comforting measures is an inherent and inseparable aspect of the nursing profession and, therefore, fundamental for humanized and high-quality care. Comfort promotes relief, consolation and encouragement to overcome unpleasant phenomena like pain, furthers the nurse-patient interaction and favors effective bonding between the stakeholders. ${ }^{24}$ The use of interpersonal and communication skills, such as listening, reflecting and welcoming the expression of feelings, is also part of the comfort process. Hence, the professionals should aim for interaction with the patients, trying to actively engage them in their care process and, for the child-juvenile clients, this need is no less important, allowing them to establish the comfort measures that are most appropriate to their needs, which contributes to their health promotion. 
The role of spirituality and religion also stands out in the search to promote the patients' comfort..$^{25}$ To support the development of pain relief strategies, it is also important for the nurses, as well as the other health team professionals, to understand the influence of spirituality in the treatment process of children and adolescents with cancer. They should know the patients' spiritual practices and sources of strengthening, and also further their access to the spiritual resources they need, encouraging them and strengthening their faith. ${ }^{25}$ Spiritual care is a challenge for the professionals, who should be available to listen to the children and adolescents' needs, respecting their beliefs and values, acknowledging communication among the health team, patients and relatives as an essential tool. ${ }^{26}$

For the sake of effective pain treatment, nonpharmacological and pharmacological interventions often need to be associated, which consist in the use of analgesic drugs that vary with the pain intensity. In Brazil, in the child and adolescent population, paracetamol and dipyrone are used more frequently to treat mild to moderate pain; codeine and tramadol for moderate to intense pain; morphine, fentanyl and methadone to relieve moderate and intense chronic pain. Adjuvant drugs like dexamethasone and amitriptyline, for example, are used to reduce the levels of anxiety, minimize the side effects or even to enhance the analgesia. ${ }^{27}$ In that sense, the study participants mentioned that analgesics only are not sufficient to effectively relieve their pain, underlining the need for complementary practices to relieve cancer pain in pediatrics.

This research comes with limitations, which should be considered, for example, with regard to the predominance of female participants. The gender can influence the perception, response and coping mechanisms with the painful situations the adolescents experience. ${ }^{28}$ Besides the gender, the adolescents' pain manifestations are subject to cultural influences. In some societies, male adolescents showed to be capable of bearing the pain without manifesting it, as that could indicate weakness, while girls demonstrate greater sensitivity to pain and, as they manifest it more clearly, are non-pharmacological resources more frequently for relief. ${ }^{29}$

Another limitation is the possibility that the adolescents felt inhibited to talk about the research problem in the presence of their mother, despite the option to decide on her presence during the interview or not. According to the literature in this area, some adolescents tend not to report their pain, afraid of some limitations due to their parents' overprotection and, in addition, may hide it when feeling that their participation in the treatment decisions are threatened. ${ }^{30}$ Hence, the testimonies of the adolescents who chose to have their mothers present during the interviews may have been broader in the mothers' absence.

In addition, a single meeting with each adolescent can be considered as another study limitation, considering that multiple approaches of the participants, at different times and in different treatment phases, could have enhanced the pain relief strategies, mainly of the non-pharmacological type. Although the participants used these measures most and considered them the most relevant, it should be mentioned that pain is multidimensional ${ }^{18}$ and grants each person a peculiar experience, thus allowing each adolescent to try out and adopt the best strategy for him/herself.

These research results emphasize that the professionals who deal with pain assessment and management involving these patients should take into account their maturity and developmental phase, in order to better understanding certain behaviors, attitudes and strategies the adolescents adopt in view of their painful experiences. ${ }^{28}$

\section{FINAL CONSIDERATIONS}

These study results indicate that the adolescents clearly report the strategies they consider effective to relieve their pain. The participants usually combine the non-pharmacological strategies (such as family presence, comforting measures, positive thinking, praying, cooperation during procedures and distraction by playing, music, reading, games and television) with pharmacological measures, as they consider that, when isolated, the latter are hardly effective.

Therefore, it is fundamental for health professionals to know and stimulate the nonpharmacological practices, as well as to develop skills to articulate and share their own knowledge with that of their patients and caregivers, with sensitivity to listen to them and willingness to use all feasible measures in order to achieve the comforting measures with the best results. 


\section{REFERENCES}

1. International Association for Study of Pain - IASP. Classification of chronic pain. 2 ed. 2011 [acesso 2013 Fev 02]. Disponível em: http:/ / www.iasp-pain. org/AM/Template.cfm?Section=Classification_of_ Chronic_Pain\&Template $=/ \mathrm{CM} /$ ContentDisplay. cfm\&ContentID $=16283$

2. Lu Q, Krull KR, Leisering W, Owen JE, Kawashima $\mathrm{T}$, Tsao JC, et al. Pain in long-term adult survivors of childhood cancers and their siblings: a report from the Childhood Cancer Survivor Study. Pain. 2011 Nov; 152(11):2616-24.

3. Erickson JM, MacPherson CF, Ameringer S, Baggott C, Linder L, Stegenga K. Symptoms and symptom clusters in adolescents receiving cancer treatment: a review of the literature. Int J Nurs Stud. 2013 Jun; 50(6): 847-869.

4. Instituto Nacional de Câncer, Instituto Ronald Mcdonald. Diagnóstico precoce do câncer na criança e no adolescente. $2^{\mathrm{a}}$ ed. Rio de Janeiro (RJ): INCA; 2011.

5. Ameringer S. Barriers to pain management among adolescents with cancer. Pain Manag Nurs. 2010 Dec; 11(4):224-33.

6. Silva MS, Pinto MA, Gomes LMX, Barbosa TLA. Dor na criança internada: a percepção da equipe de enfermagem. Rev Dor. 2011 Out-Dez; 12(4):314-20.

7. Kohlsdorf M. Aspectos psicossociais no câncer pediátrico: estudo sobre literatura brasileira publicada entre 2000 e 2009. Psicol Rev. 2010 Ago;16(2):271-94.

8. Stinson JN, Jibb LA, Nguyen C, Nathan PC, Maloney AM, Dupuis LL, et al. Development and testing of a multidimensional iPhone pain assessment application for adolescents with cancer. J Med Internet Res. 2013 Mar; 15(3):e51.

9. Leo RJ, Srinivasan SP, Parekh S. The role of the mental health practitioner in the assessment and treatment of child and adolescent chronic pain. Child Adolesc Ment Health. 2011 Fev; 16(1):2-8.

10. Ministério da Saúde (BR), Conselho Nacional de Saúde, Comissão Nacional de Ética em Pesquisa. Resolução n. 196 de 10 de outubro de 1996: diretrizes e normas regulamentadoras de pesquisa envolvendo seres humanos. Brasília (DF): MS; 1996.

11. Mayan MJ. Una introducción a los métodos cualitativos: módulo de entrenamiento para estudiantes y profesionales. Edmonton (AB): Qual Institute Press, 2001.

12. Palombo PAV, Medeiros VCC. Controle da dor aguda no pós-operatório imediato. Rev Enferm UNISA. 2001; 1(2):57-61.

13. Barros L. Dor pediátrica associada a procedimentos médicos: contributos da psicologia pediátrica. Temas Psicol. 2010 Jul-Dez; 18(2):295-306.

14. Pacciulio AM. Estratégias de enfrentamento do tratamento quimioterápico na perspectiva de crianças com câncer hospitalizadas [dissertação]. Ribeirão Preto (SP): Universidade de São Paulo. Escola de Enfermagem de Ribeirão Preto; 2012.

15. Gomes IP. Influência do ambiente na percepção das crianças em quimioterapia ambulatorial [dissertação]. João Pessoa (PB): Universidade Federal da Paraíba. Centro de Ciências da Saúde; 2011.

16. Ferreira MT, Reis PED, Gomes IP. Antineoplasic chemotherapy extravasations prevent: an integrative review. Braz J Nurs [Online]. 2008 [acesso 2012 Nov 01]; 7(3). Disponível em: http://www. objnursing.uff.br/index.php/nursing/article/ view/j.1676-4285.2008.1838

17. Cicogna EC, Nascimento LC, Lima RAG. Children and adolescents with cancer: experiences with chemotherapy. Rev Latino-Am Enferm. 2010 SetOut; 18(5):869-72.

18. Pessini L. Cuidados paliativos: alguns aspectos conceituais, biográficos e éticos. Prática Hospitalar. 2005 Set-Out; 8(41):107-12.

19. Pimenta CAM. Dor oncológica: bases para avaliação e tratamento. In: Pessini L, Bertachini L, organizadores. Humanização e cuidados paliativos. São Paulo (SP): Edições Loyola; 2004.

20. Kwekkeboom KL, Bumpus M, Wanta B, Serlin RC. Oncology nurses' use of nondrug pain interventions in practice. J Pain Symptom Manage. 2008 Jan; 35(1):83-94.

21. Landier W, Tse AM. Use of complementary and alternative medical interventions for the management of procedure-related pain, anxiety, and distress in pediatric oncology: an integrative review. J Pediatr Nurs. 2010 Dec; 25(6):566-79.

22. Deslandes SF, organizador. Humanização dos cuidados em saúde: conceitos, dilemas e práticas. Rio de Janeiro (RJ): Fiocruz; 2006.

23. Silva LDG, Tacla MTGM, Rossetto EG. Manejo da dor pós-operatória na visão dos pais da criança hospitalizada. Esc Anna Nery Rev Enferm. 2010 Jul-Set; 14(3):519-26.

24. Pott FS, Stahlhoefer T, Felix JVC, Meier MJ. Medidas de conforto e comunicação nas ações de cuidado de enfermagem ao paciente crítico. Rev Bras Enferm. 2013 Mar-Abr; 66(2):174-9.

25. Nascimento LC, Santos TFM, Oliveira FCS, Pan R, Flória-Santos M, Rocha SMM. Spirituality and religiosity in the perspectives of nurses. Texto Contexto Enferm [online]. 2013 Jan-Mar [acesso 2013 Dez 05]; 22(1):52-60. Disponível em: http://www. scielo.br/pdf/tce/v22n1/07.pdf

26. Paula ES, Nascimento LC, Rocha SMM. Religião e espiritualidade: experiência de famílias de crianças com insuficiência renal crônica. Rev Bras Enferm. 2009 Jan-Fev; 62(1):100-6.

27. Mencía S, López-Herce J, Freddi N. Analgesia and sedation in children: practical approach for the 
most frequent situations. J Pedriatr. 2007 Mai; 83(2 Suppl):S71-82.

28. Neale KL. The fifth vital sign: chronic pain assessment of the adolescent oncology patient. J Pedriatr Oncol Nurs. 2012 Jul-Ago; 29(4):185-98.

29. Hechler T, Chalkiadis GA, Hasan C, Kosfelder J,
Meyerhoff U, Vocks S, Zernikow B. Sex differences in pain intensity in adolescents suffering from cancer: differences in pain memories?. J Pain. 2009 Jun; 10(6):586-93.

30. Amering S. Barries to pain management among adolescents with cancer. Pain Manag Nurs. 2010 Dec; 11(4):224-33. 